\title{
Effects of constraint-induced movement therapy as a rehabilitation strategy for the affected upper limb of children with hemiparesis: systematic review of the literature
}

\section{Efeitos da terapia de movimento induzido por restrição como estratégia de} reabilitação do membro superior acometido de crianças hemiparéticas: revisão sistemática da literatura

Nascimento LR', Glória AE², Habib ES³

\begin{abstract}
Background: Hand function impairment is the main disability among children with hemiplegic cerebral palsy. They start to perform most motor tasks exclusively with their unaffected upper limb, thereby causing a phenomenon described as learned nonuse. To minimize this phenomenon, constraint-induced movement therapy (CIMT) is emerging as a rehabilitation strategy for improving the functional use of the affected upper limb. Objective: The aim of this study was to conduct a systematic review of the literature on the effects of CIMT among children with hemiparetic cerebral palsy. Method: This was a systematic review of the literature using randomized clinical trials to analyze the effects of CIMT on the functional performance of the affected upper limb among children with hemiparesis. Results: Five studies fulfilled the inclusion criteria, and the methodological quality ranged from 2 to 6 (4.4 \pm 1.36$)$, according to the PEDro scale. The studies included involved a total of 99 individuals who showed that CIMT had positive effects, compared with other rehabilitation strategies or no therapy. However, there was considerable variation between the studies regarding the measurement instruments used and the outcomes evaluated. Conclusion: Although the studies achieved positive results, it is difficult to draw any clear-cut conclusion regarding the effectiveness of CIMT because of the small number of studies and their methodological differences.
\end{abstract}

Key words: cerebral palsy; hemiparesis; rehabilitation; upper limb.

\section{Resumo}

Contextualização: A deficiência de função manual é a principal incapacidade em crianças com paralisia cerebral do tipo hemiplégica, as quais passam a realizar a maioria das tarefas motoras exclusivamente com o membro superior não acometido, determinando um fenômeno descrito como desuso aprendido. Para minimizar esse fenômeno, a terapia de movimento induzido por restrição (TMIR) emerge como estratégia de reabilitação para melhorar o uso funcional do membro superior acometido. Objetivo: O propósito desse estudo foi conduzir uma revisão sistemática da literatura para os efeitos da TMIR em crianças com hemiparesia devido à paralisia cerebral. Método: Revisão sistemática da literatura com ensaios clínicos aleatorizados analisando os efeitos da TMIR no desempenho funcional do membro superior acometido em crianças com hemiparesia. Resultados: Cinco estudos preencheram os critérios de inclusão e a qualidade metodológica variou entre 2 e $6(4.4 \pm 1.36)$ de acordo com a escala PEDro. Os estudos incluídos envolveram um total de 99 indivíduos e demonstraram efeitos positivos da TMIR em comparação a outras estratégias de reabilitação ou ausência de terapia. Entretanto, foram encontradas variações consideráveis nos estudos em relação aos instrumentos de medidas utilizados e os desfechos dos estudos. Conclusão: Embora os estudos tenham alcançado resultados positivos, a definição de uma conclusão sobre a efetividade da TMIR é dificultada em função do pequeno número de estudos e suas diferenças metodológicas.

Palavras-chave: paralisia cerebral; hemiparesia; reabilitação; membro superior.

Received: 02/09/2008 - Revised: 03/11/2008 - Accepted: 02/12/2008

\footnotetext{
'Department of Basic Sciences, Universidade Federal dos Vales do Jequitinhonha e Mucuri (UFVJM), Diamantina (MG), Brazil

${ }^{2}$ Physical therapist

${ }^{3}$ Department of Physical Therapy, Centro Universitário de Belo Horizonte, Belo Horizonte (MG), Brazil

Correspondence to: Lucas Rodrigues Nascimento, Rua Contria, 1500 - apto 1203B, Grajaú, CEP 30430-460, Belo Horizonte (MG), Brazil, e-mail: Irn@ufmg.br
} 


\section{Introduction $: \therefore$.}

Cerebral palsy (CP) is defined as a group of permanent disorders of movement and posture development that are attributed to nonprogressive disturbances that occurred in the developing fetal or infant brain. It is characterized by the inability to control motor functions and potentially has a negative effect on such children's overall development by affecting the ability to explore, speak, learn and become independent ${ }^{1-3}$. Spastic hemiplegia is one of the types of $\mathrm{CP}$ and accounts for more than one third of new cases. It causes spasticity and motor-functional disability contralateral to the brain damage ${ }^{2,4,5}$.

Gordon, Charles and Wolf ${ }^{6}$ stated that impaired hand function is a major disability among children with hemiplegic cerebral palsy (HCP). Because of this, such children usually have considerable difficulty in using the affected upper limb to perform tasks, including two-handed activities, thereby undermining their independence and quality of life ${ }^{6-8}$.

As an adaptive mechanism due to disability of the affected upper limb, individuals with HCP perform most of their motor tasks exclusively with their unaffected upper limb, thereby causing the phenomenon of learned nonuse ${ }^{6,9}$. The description of this process was derived from basic research on monkeys and its concept was then generalized to include humans affected by stroke and other types of injury to the central nervous system (CNS). The general principle states that a portion of the motor deficit is caused not only by the injury per se but also by a learning phenomenon due to suppression of the movement of the affected limb ${ }^{10}$.

Specifically, learned nonuse occurs as a result of the conditioned suppression of movement, secondary to unsuccessful efforts to make voluntary movements during the acute phase of a neurological injury. Such individuals initially try to use the affected limb but, because of physiological reactions in the nervous system during the acute phase of the injury, there are no observable voluntary movements'. Successive failure leads these individuals to learn to use the unaffected limb when performing tasks, thereby leading to learned nonuse. This nonuse is believed to be responsible for a gradual reduction in the cortical representation of the affected limb, which would prevent its use during the chronic phase of a neurological injury ${ }^{9-11}$.

Considering the principles of learned nonuse, an intervention strategy called constraint-induced movement therapy (CIMT) has been developed. This consists of placing the unaffected upper limb in a cast and training of the contralateral $\mathrm{limb}^{6}$. Evidence from using CIMT among adults who have suffered strokes suggests that it has beneficial results. These have been identified mainly through tests on the levels of upper-limb impairment and focal disability and through subjective measurements. Such tests have suggested that intensive behavioral training helps to transfer the gains achieved in the clinic to life outside the clinic ${ }^{11}$. However, the use of this therapy among children with HCP is still controversial. Thus, the aim of this study was to conduct a systematic review of the literature on the effects of CIMT on children with HCP.

\section{Methods : :}

A literature search with no limits on data or language was conducted in the databases Medline, PEDro and PSycINFO between April and July 2008. The key words used were constraintinduced therapy, cerebral palsy, hemiplegia and hemiparesis. To identify unpublished research, an active search in the library of Universidade Federal de Minas Gerais was conducted using the equivalent keywords in Portuguese.

During study selection, the initial analysis was made by evaluating titles and abstracts, and this was conducted by two independent and blinded researchers. When the title and abstract were unclear, the article was read in full to eliminate uncertainties $^{12}$. In case of disagreement among the researchers, a further assessor would review the selection and evaluation parameters.

The articles identified by the search strategy were evaluated in terms of the following inclusion criteria: (1) study design: randomized controlled trial; (2) population composed of children affected by cerebral palsy that caused hemiparesis; (3) intervention strategy using CIMT; (4) control group using an intervention other than CIMT or no intervention; and (5) outcome relating to hemiparetic upper-limb function.

The studies that met the inclusion criteria were evaluated for methodological quality in accordance with the PEDro scale $^{13}$. The PEDro scale is an 11-item scale designed for rating the methodological quality (internal validity and statistical information) of randomized controlled trials. Each item satisfied (except for item 1, which, unlike the other items on the scale, relates to external validity) contributes one point to the total PEDro score (range: 0 to 10 points) ${ }^{13,14}$. When possible, the scores described on the websites of the electronic databases were used ${ }^{13}$. When this score was not available, two blinded assessors evaluated the article to attribute a score.

\section{Data analysis}

Because of the insufficient data presented in some studies and the variety of different instruments used for measurements, no statistical analysis (meta-analysis) was performed.

Thus, a descriptive analysis of the results is presented below. When possible, the percentage differences between the treated and control groups and the minimal clinically important 
difference (MCID; defined as a change of at least $10 \%$ in the maximum score of the scale used) were analyzed. The MCID makes it possible to measure change in relation to the baseline and to avoid a ceiling effect in the scales ${ }^{11}$.

\section{Results $: \because$.}

The systematic search of the literature resulted in identifying 34 studies on hemiparetic children and treatments relating to CIMT. Among these 34 studies, five were randomized clinical trials (RCT), and these were included in this systematic review. Thirteen studies were literature reviews and the other sixteen studies did not have an RCT-supported design or did not have any direct relationship with the topic under examination and therefore were not included in this review.

The studies included involved a total of 99 subjects (49 treated with CIMT and 50 as the control group). The number of participants involved in each trial ranged from 16 to 25 $(19.8 \pm 3.25)$. The methodological quality, as assessed using the PEDro scale, ranged from 2 to $6(4.4 \pm 1.36)$. The study by Brandão and Mancini ${ }^{15}$ was the only one that had not received prior classification using this scale, and thus, it was duly classified for the purposes of the present study, by two blinded assessors. The inclusion criteria for participation in these five studies varied and the total duration of the intervention ranged from 10 to 30 days (20.6 \pm 6.34 ). The duration of cast use and the use or absence of complementary therapies such as physical therapy, occupational therapy or home exercises also differed between the studies (Tables 1 and 2).

The study characteristics and results (summarized as either "+" when positive for the experimental group or "0" when there was no difference in relation to the control group ${ }^{11}$ ) and the final score on the methodological scale are presented in Table 2. All the studies examined found that CIMT presented favorable characteristics as an upper-limb rehabilitation strategy. Table 3 presents the absolute results for outcomes in the studies, the percentage change in comparisons between phases and the percentage difference in variations between groups, with regard to the total variation allowed by the scale used in each study. For all studies, there was more improvement in the intervention group than in the control group, and this improvement was clinically significant for most of the variables analyzed (MCID >10\%). There was considerable variation between instruments used and between the methods used to evaluate the outcomes presented. The instruments most used were the Emerging Behaviors Scale (two studies ${ }^{16,17}$ ), Pediatric Motor Activity Log (two studies ${ }^{16,17}$ ) and Jebsen-Taylor Test of Hand Function (two studies ${ }^{15,18}$ ).

\section{Discussion $\because:$.}

Constraint-induced movement therapy is emerging as a treatment approach with the potential to improve the functional use of the affected upper limb among children with HCP.

Table 1. Randomized clinical trials included in this systematic review.

\begin{tabular}{|c|c|c|c|c|}
\hline Authors & Outcomes & Duration & Reassessment & Inclusion criteria \\
\hline Willis et al. ${ }^{19}$ & PDMS & 1 month & $\begin{array}{l}1 \text { month } \\
6 \text { months (follow-up) }\end{array}$ & Presence of hemiparesis (at least 1 year); age between 1 and 8 years \\
\hline Taub et al. ${ }^{16}$ & $\begin{array}{l}\text { EBS } \\
\text { PMAL } \\
\text { TAUT }\end{array}$ & 21 days & $\begin{array}{l}3 \text { weeks } \\
3 \text { and } 6 \text { months } \\
\text { (only CIMT) }\end{array}$ & $\begin{array}{c}\text { Diagnosis of cerebral palsy leading to hemiparesis; health subjects; } \\
\text { age } \leq 8 \text { years - and for children }<18 \text { months: MRI confirming an } \\
\text { etiology of stroke }\end{array}$ \\
\hline Charles et al. ${ }^{18}$ & $\begin{array}{c}\text { JTHF } \\
\text { BTMP (item 8) } \\
\text { CFUS } \\
\text { TPD } \\
\text { HHD } \\
\text { MAS }\end{array}$ & 10 days & $\begin{array}{l}1 \text { week } \\
1 \text { and } 6 \text { months } \\
\text { (follow-up) }\end{array}$ & $\begin{array}{l}\text { Ability to extend the wrist at least } 20^{\circ} \text { and the fingers } 10^{\circ} \text { from full } \\
\text { flexion at the MCF; a } 50 \% \text { difference between limbs on JTHF; score } \\
\text { within } \pm 1.0 \text { of the mean on the KBIT }\end{array}$ \\
\hline Deluca et al. ${ }^{17}$ & $\begin{array}{l}\text { QUEST } \\
\text { PMAL } \\
\text { EBS }\end{array}$ & 21 days & 3 weeks & $\begin{array}{l}\text { Diagnosis of cerebral palsy with asymmetric involvement of the } \\
\text { upper limb; age } \leq 8 \text { years; health subjects }\end{array}$ \\
\hline Brandão and Mancini13 & $\begin{array}{c}\text { CAUT } \\
\text { JTHF } \\
\text { ABILHAND-kids } \\
\text { PEDI }\end{array}$ & $\begin{array}{c}2 \text { weeks }(\text { CIMT) + } \\
1 \text { week } \\
\text { (training) }\end{array}$ & $\begin{array}{l}3 \text { weeks } \\
1 \text { month } \\
\text { (follow-up) }\end{array}$ & $\begin{array}{l}\text { Diagnosis of hemiplegic spastic cerebral palsy; age between } 4 \text { and } \\
8 \text { years; ability to perform activities of the study; attendance of OT } \\
\text { sessions }\end{array}$ \\
\hline
\end{tabular}

PDMS: Peabody Developmental Motor Scales; EBS: Emerging Behaviors Scale; PMAL: Pediatric Motor Activity Log; TAUT: Toddler Arm Use Test; MRI: Magnetic Resonance Imaging; JTHF: Jebsen-Taylor Test of Hand Function; BTMP: Bruininks-Oseretsky Test of Motor Proficiency; CFUS: Caregiver Functional Use Survey; TPD: two-point discrimination; HHD: handheld dynamometer; MAS: Modified Ashworth Scale; MCF: metacarpophalangeal joints; KBIT: Kaufman Brief Intelligence Test; QUEST: Quality of Upper Extremity Skills Test; CAUT: Child Arm Use Test; ABILHAND-kids: Measure of manual ability; PEDI: Pediatric Evaluation of Disability Inventory; OT: Occupational therapy. 
Thus, the present review evaluated the effectiveness of this type of intervention using the highest-level evidence available.

The study by DeLuca et al. ${ }^{17}$ presented evidence on the use of CIMT among hemiparetic children, including the acquisition of new behavioral patterns, as shown by the Emerging Behaviors Scale. The changes observed may be explained by a combination of the factors of which CIMT is composed, in just a single therapeutic process: casting of the unaffected upper limb, treatment in a natural setting and intensive treatment for the affected upper limb. However, these authors suggest that these components should be broken down to identify the best intervention strategies and minimize the treatment costs and duration. Similar evidence comes from the study by Willis et al. ${ }^{19}$, in which a specific type of CIMT known as

Table 2. Study characteristics.

\begin{tabular}{|c|c|c|c|c|c|}
\hline$N$ & Treatment & Control & $\begin{array}{l}\text { Result } \\
(+ \text { or } 0)\end{array}$ & Crossover & $\begin{array}{l}\text { Score } \\
\text { PEDro }\end{array}$ \\
\hline $25^{19}$ & $\begin{array}{l}\qquad n=12 \\
\text { Casting of the unaffected upper limb for } 1 \text { month. Continuation of } \\
\text { the PT and OT routines. }\end{array}$ & $\begin{array}{l}\qquad \mathrm{n}=13 \\
\text { Continuation of the PT and OT routines, } \\
\text { without additional treatment. }\end{array}$ & + & $\begin{array}{l}6 \text { months } \\
(\mathrm{n}=17) \\
7 \text { in CIMT } \\
10 \text { control }\end{array}$ & 2 \\
\hline $18^{16}$ & $\begin{array}{l}\qquad \mathrm{n}=9 \\
\text { Casting of the unaffected upper limb + functional training of the } \\
\text { contralateral limb with PT or } 0 T-6 \text { hours/day for } 21 \text { days. }\end{array}$ & $\begin{array}{l}\text { Continuation of previous intervention } \\
\text { programs - PT or OT - mean of } 2.2 \text { hours/ } \\
\text { week. }\end{array}$ & + & No & 5 \\
\hline $22^{18}$ & $\begin{array}{c}n=11 \\
\text { Casting of the unaffected upper limb + functional training of the } \\
\text { contralateral limb }-6 \text { hours/day for } 10 \text { days. Home exercises for } \\
1 \text { hour/day. }\end{array}$ & $\begin{array}{c}\mathrm{n}=11 \\
\text { No treatment during study period. }\end{array}$ & + & No & 5 \\
\hline $18^{17}$ & $\begin{array}{l}\qquad n=9 \\
\text { Casting of the unaffected upper limb + functional training of the } \\
\text { contralateral limb with PT or OT }-6 \text { hours/day for } 21 \text { days. }\end{array}$ & $\begin{array}{l}n=9 \\
\text { Continuation of previous intervention } \\
\text { programs - school or private therapy - } \\
\text { mean of } 2.2 \text { hours/week. }\end{array}$ & + & $\begin{array}{l}6 \text { weeks } \\
(\mathrm{n}=8) \text {; only for } \\
\text { subjects previously } \\
\text { in control group. }\end{array}$ & 4 \\
\hline $16^{15}$ & $\begin{array}{l}\qquad n=8 \\
\text { Casting of the unaffected upper limb throughout day }+3 \text { hours } \\
\text { functional training }- \text { for } 2 \text { weeks. Next week: functional training } 3 \\
\text { times/week; with no restraint. }\end{array}$ & $\begin{array}{l}\mathrm{n}=8 \\
\text { OT routine, weekly sessions. } \\
45 \text { minutes/week. }\end{array}$ & + & No & 6 \\
\hline
\end{tabular}

PT: Physical Therapy; ОT: Occupational Therapy.

Table 3. Study results: comparison between intervention and control groups.

\begin{tabular}{|c|c|c|c|c|c|c|c|c|c|c|c|c|}
\hline \multirow{2}{*}{ Authors } & \multirow{2}{*}{ Outcome } & \multicolumn{5}{|c|}{ Treatment } & \multicolumn{5}{|c|}{ Control } & \multirow{2}{*}{$\begin{array}{c}\text { Comparison } \\
\%\end{array}$} \\
\hline & & Pretest & SD & Post-test & SD & $\%$ & Pretest & SD & Post-test & SD & $\%$ & \\
\hline Willis et al. ${ }^{19}$ & PDMS & 143.2 & NA & 155.8 & NA & 6.43 & 102.2 & NA & 104.7 & NA & 1.27 & 5.16 \\
\hline \multirow[t]{4}{*}{ Taub et al. ${ }^{16}$} & EBS & 12.2 & 5.64 & 21.5 & 4.45 & 30.0 & 12.7 & 6.51 & 15.0 & 5.66 & 7.42 & 22.58 \\
\hline & PMAL (amount) & 0.8 & 0.44 & 2.8 & 1.14 & 40.0 & 1.1 & 0.75 & 1.2 & 0.82 & 2.0 & 38.0 \\
\hline & PMAL (quality) & 0.9 & 0.62 & 2.7 & 0.97 & 36.0 & 1.6 & 1.2 & 1.9 & 1.13 & 6.0 & 30.0 \\
\hline & TAUT & NA & NA & NA & NA & 53.9 & NA & NA & NA & NA & 18.0 & 35.9 \\
\hline \multirow[t]{4}{*}{ Charles et al. ${ }^{18}$} & JTHF & 361.2 & 205.4 & 278.5 & 238 & 11.49 & 314.2 & 177.5 & 301.0 & 182.2 & 1.83 & 9.66 \\
\hline & BTMP & 4.8 & 3.0 & 7.2 & 2.9 & 3.33 & 4.8 & 3.7 & 5.2 & 4.2 & 0.55 & 2.78 \\
\hline & CFUS (amount) & 2.6 & 0.7 & 3.0 & 0.7 & 8.0 & 2.6 & 0.6 & 2.3 & 0.5 & -6.0 & 14.0 \\
\hline & CFUS (quality) & 2.0 & 0.5 & 2.5 & 0.6 & 10.0 & 2.2 & 0.5 & 2.4 & 0.4 & 4.0 & 6.0 \\
\hline \multirow[t]{4}{*}{ Deluca et al. ${ }^{17 *}$} & QUEST & 22.5 & NA & 36.25 & NA & 13.75 & 31.25 & NA & 30.0 & NA & -1.25 & 15.0 \\
\hline & PMAL (amount) & 0.77 & NA & 2.88 & NA & 42.2 & 1.15 & NA & 1.19 & NA & 0.8 & 41.4 \\
\hline & PMAL (quality) & 0.92 & NA & 2.69 & NA & 35.4 & 1.61 & NA & 1.96 & NA & 7.0 & 28.4 \\
\hline & EBS & 12.37 & NA & 22.10 & NA & 31.39 & 13.16 & NA & 15.53 & NA & 7.65 & 23.74 \\
\hline
\end{tabular}

Brandão and Mancini15** NA

$\mathrm{NA}=$ not available; *Absolute values not presented; the main author lacked the data. Analysis made by approximating graphical values (not confirmed); ${ }^{* \star}$ Absolute values not presented; no return after contacting main author. Analysis by approximating graphical values was not possible. 
forced-use therapy was employed. In this, the restriction was maintained without any specific direction given for rehabilitation of the contralateral limb as a component of this intervention process, although participants were allowed to maintain routines such as physical therapy and occupational therapy. Positive results were found in the intervention group, compared with the control group, thus suggesting that the restriction component has considerable importance regarding the effectiveness of the treatment.

The results described by Taub et al. ${ }^{16}$ showed significant improvements in the quality and amount of use of the more impaired limb, compared with previous studies ${ }^{20,21}$. These improvements were explained by the combination of casting with intensive training of contralateral limb using functional activities. These authors stated that despite the increasing popularity of restraint, it would seem to be of limited value when not coupled with active training.

The other studies analyzed ${ }^{15-18}$, unlike the method of Willis et al. ${ }^{19}$, prioritized combined interventions that allowed lower intensity of restraint use (in terms of consecutive hours or days). In a study using CIMT for six hours a day over a 10-day period, Charles et al. ${ }^{18}$, found considerable evidence of benefits from the use of CIMT, considering effect sizes and changes that were retained for up to six months after the intervention. The findings suggested that the intensity of training need not be as high as that applied to hemiparetic adults (constant use of the restraint) and that periods of intense structured practice may be more important than the duration of restraint.

Increased intensity and duration of interventions have been shown to contribute towards improved performance regarding the speed of tasks and to facilitate the transition from skills characterized as inconsistent and varied to consistent and structured actions ${ }^{15,22}$. However, this progression should be undertaken with caution, because some components of interventions involving high-intensity training and restraint may lead to irritation and frustration among the children undergoing these procedures ${ }^{15}$.

Among the main modifications that have been described are improvements in the frequency and quality of movements presented by the affected limb following CIMT, as demonstrated by analysis of two-handed tasks. This evidence suggests that greater use of the affected limb is achieved during these activities, thus improving task performance in daily activities ${ }^{18}$.

According to Taub et al. $^{16}$, the changes relating to use of the affected limb, following CIMT, may increase the child's communication and social skills accompanied by signs of increased confidence and enjoyment in carrying out activities of daily life. The improvement in spontaneity of use of the affected limb also suggests that this type of intervention promotes motivation and the perception of the possibilities of using the affected limb when performing daily tasks, thereby reducing the learned nonuse ${ }^{15}$.

A new intervention approach including functional training for one week, conducted after applying the CIMT protocol, was described by Brandão and Mancini ${ }^{13}$. This method may have an important role with regard to acquiring functionality, since it allowed the acquired skills to be incorporated into tasks of daily life after removal of the restraint, thus suggesting a new protocol for CIMT. However, these different types of treatment that have been described need to be compared in order to elucidate the best intervention method using CIMT.

In general, comparisons between control groups and groups using CIMT, among hemiparetic children, are still made by considering much longer interventions for the group receiving the casts. This may overestimate the real effects from the intervention. It has been shown $n^{15,16,23}$ that control groups need to be offered training sessions at the same intensity as that applied to experimental groups. If this is not done, the positive results found from intervention groups might be attributable to differences in the intensity of the treatment and not from the type of treatment studied.

This systematic review has presented important evidence regarding positive effects from CIMT as an intervention strategy for upper-limb rehabilitation among hemiparetic children. Nevertheless, the number of studies on this topic is limited and there are considerable methodological differences between them, thus leading to inconclusive results. The studies use different instruments and scales to analyze the intervention effects, and this makes it difficult to compare the results appropriately and to perform meta-analyses. We suggest that further studies should be conducted to clarify the impact of using CIMT at different intensities, to investigate methods for combining CIMT with other techniques and to analyze the environmental context within which the activities are carried out. The use of valid and reliable instruments that are capable of measuring upper-limb function, two-handed activities and outcomes relating to activities and participation should be encouraged in order to enable better comparison between studies and understanding of the impact of this intervention on children's daily lives. 


\section{References $:: 8$.}

1. O'Shea M. Cerebral palsy. Semin Perinatol. 2008;32(1):35-41.

2. Jones MW, Morgan E, Shelton JE, Thorogood C. Cerebral palsy: introduction and diagnosis (part I). J Pediat Health Care. 2007;21(3):146-52.

3. Rosenbaum P, Paneth N, Leviton A, Goldstein M, Bax M, Damiano D, et al. A report: the definition and classification of cerebral palsy April 2006. Dev Med Child Neurol. 2007;109:8-14.

4. Platt MJ, Pharoah POD. Epidemiology of cerebral palsy. Current Paediatrics. 1995;5:151-5.

5. Charles J, Lavinder G, Gordon AM. Effects of constraint-induced therapy on hand function in children with hemiplegic cerebral palsy. Pediatr Phys Ther. 2001;13(2):68-76.

6. Gordon AM, Charles JA, Wolf SL. Efficacy of constraint-induced movement therapy on involved upper-extremity use in children with hemiplegic cerebral palsy is not age-dependent. Pediatrics. 2006;117(3):363-73.

7. Gordon AM, Schneider JA, Chinnan A, Charles JR. Efficacy of a handarm bimanual intensive therapy (HABIT) in children with hemiplegic cerebral palsy: a randomized controlled trial. Dev Med Child Neurol. 2007;49(11):830-8.

8. Boyd RN, Morris ME, Graham HK. Management of upper limb dysfunction in children with cerebral palsy: a systematic review. Eur J Neurol. 2001;8 Suppl 5:150-66.

9. DeLuca SC, Echols K, Ramey SL, Taub E. Pediatric constraint-induced movement therapy for a young child with cerebral palsy: two episodes of care. Phys Ther. 2003;83(11):1003-13.

10. Taub E, Uswatte G, Mark VW, Morris DM. The learned nonuse phenomenon: implications for rehabilitation. Eura Medicophys. 2006;42(3):241-55.

11. Bonaiuti D, Rebasti L, Sioli P. The constraint induced movement therapy: a systematic review of randomized controlled trials on the adult stroke patients. Eura Medicophys. 2007;43(2):139-46.

12. Sampaio RF, Mancini MC. Estudos de revisão sistemática: um guia para síntese criteriosa da evidência científica. Rev Bras Fisioter. 2007;11(1):83-8.
13. PEDro [homepage na Internet]. Austrália: Physiotherapy Evidence Database; 1999. [atualizada em 2009 Feb 02; acesso em 2008 Nov]. Disponível em: http://www.pedro.fhs.usyd.edu.au/index.html

14. Maher CG, Sherrington C, Herbert RD, Moseley AM, Elkins M. Reliability of the PEDro scale for rating quality of randomized controlled trials. Phys Ther. 2003;83(8):713-21.

15. Brandão MM, Mancini MC. Efeitos da terapia de movimento induzido por restrição na funcionalidade de crianças com paralisia cerebral [dissertação]. Belo Horizonte, MG. Escola de Educação Física, Fisioterapia e Terapia Ocupacional-Universidade Federal de Minas Gerais; 2007.

16. Taub E, Ramey SL, DeLuca S, Echols K. Efficacy of constraint-induced movement therapy for children with cerebral palsy with asymmetric motor impairment. Pediatrics. 2004;113(2):305-12.

17. DeLuca S, Echols K, Law CR, Ramey SL. Intensive pediatric constraintinduced therapy for children with cerebral palsy: randomized, controlled, crossover trial. J Child Neurol. 2006;21(11):931-8.

18. Charles JR, Wolf SL, Schneider JA, Gordon MA. Efficacy of a childfriendly form of constraint-induced movement therapy in hemiplegic cerebral palsy: a randomized control trial. Dev Med Child Neurol. 2006;48(8):635-42.

19. Willis JK, Morello A, Davie A, Rice JC, Bennett JT. Forced use treatment of childhood hemiparesis. Pediatrics. 2002;110(1):94-6.

20. Palmer FB, Shapiro BK, Wachtel RC, Allen MC, Hiller JE, Harryman SE, et al. The effects of physical therapy on cerebral palsy: a controlled trial in infants with spastic diplegia. N Engl J Med. 1988;318(13):803-8.

21. Scherzer AL, Mike V, Ilson J. Physical therapy as a determinant of change in the cerebral palsied infant. Pediatrics. 1976;58(1):47-52.

22. Manoel Ede J, Conolly KJ. Variability and the development of skilled actions. Int J Psychophysiol. 1995;19(2):129-47.

23. Dromerick AW. Evidence-based rehabilitation: the case for and against constraint-induced movement therapy. J Rehabil Res Dev. 2003;40(1):vii-ix. 